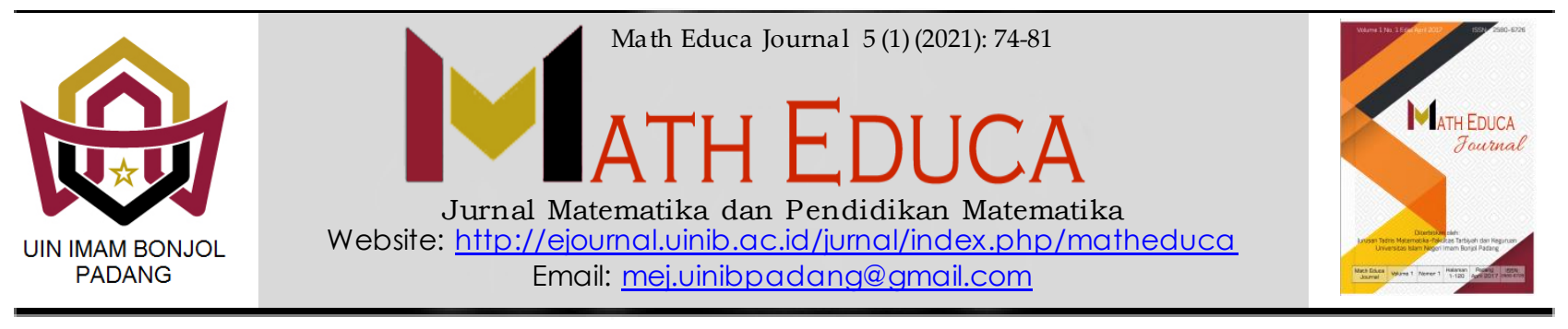

\title{
ANALISIS PENJUALAN DAN PERSAINGAN AIR MINERAL KEMASAN BOTOL SELAMA PANDEMI COVID-19 DI KOTA MEDAN MENGGUNAKAN RANTAI MARKOV ORDE DUA
}

\author{
'Freddy Giawa, ${ }^{2}$ Riri Syafitri Lubis, ${ }^{3}$ Rina Widyasari \\ 1,2,3Program Studi Matematika, Fakultas Sains dan Teknologi, Universitas Islam Negeri Sumatera Utara \\ E-mail: ' freddy.giawa@gmail.com, 2 riri syafitri@uinsu.ac.id, 3 rina widyasari@uinsu.ac.id
}

Received: February 2021; Accepted: March 2021; Published: April 2021

\begin{abstract}
Markov chain is a method used to identify variables in the present, which is based on past variables in order to obtain an estimate of the probability of these variables in the future. The CoVid-19 virus outbreak has also had a negative impact on economic problems, because this pandemic resulted in a decrease in sales of mineral water. in bottles that experienced a decline in sales results during the COVID-19 pandemic. The formulation of the problem of how companies compete during Covid-19 which continues to experience a decline in sales?. Based on the results of this study, there is a large chance of a second order transition, namely AQUA products in September, which is 61\%, an increase of $0.39 \%$ from October, in October it was 61.39, a decline of $0.02 \%$ so that in November it was $61.37 \%$ while Le Mineral products in September were 39\%, decreased $0.39 \%$ from October, October was $38.61 \%$, experienced a fix in November so November was $38.61 \%$.
\end{abstract}

Keywords: Sales, AQUA, Le Minerale, Marcov Chain Orde 2

\section{Abstrak}

Rantai markov adalah suatu metode yang digunakan untuk mengidentifikasi variabel variabel pada masa sekarang yang didasarkan pada variabel masa lalu sehingga didap atkan perkiraan kemungkinan variabel tersebut dimasa yang akan datang. Bencana wabah virus CoVid-19 berdampak buruk juga terhadap masalah ekonomi, sebab pandemic ini mengakibatkan penurunan terhadap penjualan air mineral. dalam kemasan botol yang mengalami penurunan hasil penjualan selama pandemi COVID-19.rumusan masalah bagaimana cara perusahaan untuk bersaing selama covid-19yang terus mengalami penurunan penjualan?tujuan Penelitian ini adalah untuk mengetahui bagaimana perusahaan bersaing selama covid 19 yang dapat diprediksi terus mengalami penurunan penjualan. Berdasarkan hasil Penelitian ini besar peluang peralihan di masa mendatang orde dua yaitu produk AQUA pada September adalah 61\% mengalami kenaikan 0,39\% dari Oktober, pada Oktober adalah 61,39 mengalami penurunan 0,02\% sehingga pada November adalah 61,37\% sedangkan produk Le Mineral pada September adalah 39\% mengalami penurunan 0,39\% dari Oktober, Oktober adalah 38,61\% mengalami penetapan pada November sehingga November 38,61\%.

Kata Kunci: Penjualan, AQUA, Le Minerale, Rantai Markov Orde Dua

\footnotetext{
${ }^{*}$ Corresponding author.

Peer review under responsibility UIN Imam Bonjol Padang.

(C) 2021 UIN Imam Bonjol Padang. All rights reserved.

p-ISSN: 2580-6726

e-ISSN: 2598-2133
} 


\section{PENDAHULUAN}

Bencana virus penyakit baru yang terjadi sampai waktu ini, masyarakat membutuhkan air minum yang layak untuk dikonsumsi manusia. Air mineral dalam kemasan adalah salah satu solusi air minum yang digunakan untuk dikonsumsi manusia sehingga banyak merek air mineral yang beredaran di pasaran sehingga hal ini dapat menimbulkan persaingan penjualan air mineral. Merek yang peneliti teliti adalah merek AQUA dan Le Minerale.

(https://www.cbncindonesia.com/efek-domino-COVID-19/).

Dua merek air mineral dalam kemasan yaitu AQUA dan Le-Minerale Persaingan dua Perusahaan Air Minum Dalam Kemasan (AMDK) merek AQUA dan Le Minerale bertarung medan perang perdagangan sebab kedua pesaing merek AQUA dan Le Minerale merupakan salah satu merek air minum dalam kemasan pilihan pangsa pasar. Sebab keduanya memiliki kualitas yang sama kuat kualitasnya.(https://tito.id/le-minerale-versus-

aqua).

Penelitian ini dilatarbelakangi oleh masalah penjualan air minum dalam kemasan terkendala menurun.hal ini berdampak buruk terhadap pencaharian perusahaan yang terancam pailit dikarenakan berkurangnya pendapatan perusahaan yang terus mengalami penurunan akibat CoVid-19 di Kota Medan.
Penelitian tentang kasus rantai markov orde dua yang sudah dilakukan peneliti sebelumnya adalah Carmen Castillo etc tahun 2012 dengan artikel berjudul "Rainflow Analysis in Coastal Engineering Using Switching Second Order Markov Models. Penelitian selanjutnya adalah G. Horvart, S.Racz, M.Telek tahun 2013 dengan jurnal berjudul "Analysis of SecondOrder Markov Rewards Models".penelitian yang terakhir dilakukan oleh Syarifah Inayati dan Nurhaimi tahun 2019 dengan jurnal berjudul "Penggunaan Rantai Markov Orde Dua Untuk Menganalisis Ketersediaan Pemasaran Produk Sampo Z di Swalayan Pamella 1 ".

Rumusan masalah pada artikel ini adalah bagaimana persaingan penjualan produk air minum dalam kemasan botol selama pandemi COVID-19 di Kota Medan, dengan batasan responden 100 orang pekerja kantor, sehingga tujuan penelitian ini adalah untuk mengetahui merek apa yang dipilih responden perkerja kantor untuk mewakili pekerja kantor Kota Medan.

\section{METODE PENELITIAN}

\section{Proses Stokastik}

Proses Stokastik merupakan suatu keluarga peubah acak $\{\mathrm{X}(\mathrm{t})\}$ yang tertentu dalam suatu ruang sampel, dimana $t$ merupakan parameter himpunan t (Saputra, 2018) 


\section{Rantai Markov Orde satu}

Rantai markov orde satu merupakan rantai markov yang bergantung pada satu nilai sebelumnya .peluang transisi orde pertama atau 1- langkah dimodelkan sebagai persaman sebagai berikut (Inayati dan Muhaimi, 2019). $p\left(x_{t+1}=j \mid x_{t}=1, x_{t-1}=i_{1}, x_{t-2}=i_{2}, \ldots, x_{0}=i_{0}\right)=P\left(X_{t+1}=j \mid X_{t}=i\right)=p_{i j}$.

\section{Rantai Markov Orde Dua}

Rantai markov orde dua merupakan rantai markov yang bergantung pada dua atau lebih nilai sebelumnya peluang transisi orde dua langkah dimodelkan sebagai berikut (Inayati dan Muhaimi, 2019).

$$
\begin{aligned}
P\left(X_{t+1}\right. & \left.=j \mid X_{t}=1, X_{t-1}=i_{1}, X_{t-2}=i_{2}, \ldots, X_{0}=i_{0}\right) \\
& =P\left(X_{t+1}=j \mid X_{t}=i, X_{t-1}=t_{t-1}\right)=P_{i j}
\end{aligned}
$$

\section{Target/Subjek Penelitian/ Populasi dan}

\section{Sampel}

Data yang digunakan dalam penelitian ini adalah data primer yang diambil dari hasil jawaban yang peneliti sebarkan kepada responden. Data ini diambil dari pegawai pekerja kantoran diantaranya adalah Bank Sumut KC Medan Sukaramai, RSUD dr Pirngadi, Kantor Lurah Bantan, Bank Mandiri dan PT Kharimantara Indonesia.

\section{Prosedur Kerja Penelitian}

1. Pengumpulan Data

2. Menganalisis Data

- Tabel data jumlah pelanggan Air Mineral dalam kemasan botol.
- Tabel transisi pelanggan kedua merek air mineral dalam kemasan botol.

- Tabel data pendapat/opini responden terhadap dua merek air mineral dalam kemasan tersebut.

3. Menerapkan rantai Markov

a. Menghitung peluang transisi air mineral dalam kemasan botol dimasa mendatang.

- Menghitung peluang transisi.

- Menghitung besar peluang transisi dimasa mendatang.

b. Menghitung peluang prediksi konsumen dua merek air mineral dalam kemasan botol berdasarkan alasan.

c. Menghitung prediksi proporsi masing masing air mineral dalam kemasan botol berdasarkan alasan pelanggan

d. Menghitung peluang transisi baru yang tidak disesuaikan.

e. Menghitung peluang transisi baru

\section{HASIL PENELITIAN}

\section{Analisis Hasil Rantai Markov Orde Satu}

Analisis data dapat dilihat pada Tabel 1. 
Tabel 1. Data Jumlah Pelanggan Sekarang dan Sebelumnya

\begin{tabular}{ccccc}
\hline Merek & $\begin{array}{c}\text { Sebelum } \\
\text { nya }\end{array}$ & Perolehan & $\begin{array}{c}\text { Kehila } \\
\text { ngan }\end{array}$ & $\begin{array}{c}\text { Saat } \\
\text { ini }\end{array}$ \\
\hline AQUA & 50 & 29 & 17 & 62 \\
\hline $\begin{array}{c}\text { Le } \\
\text { Minerale }\end{array}$ & 50 & 17 & 29 & 38 \\
\hline Jumlah & 100 & 46 & 46 & 100 \\
\hline
\end{tabular}

Sumber:. kuesioner penelitian, data diolah pada

tahun 2020

Tabel 1 merupakan jumlah pelanggan air mineral dapat dilanjutkan pada tabel 2 yaitu tabel peralihan pelanggan disajikan sebagai berikut:

Tabel 2. Kontigensi Pelanggan dari Satu Merek ke Merek Lain

\begin{tabular}{lll}
\hline Merek & Sebelumnya & Saat ini \\
\hline AQUA & $\mathbf{5 0}$ & $\mathbf{6 2}$ \\
\hline Le & $\mathbf{5 0}$ & $\mathbf{3 8}$
\end{tabular}

Minerale

Sumber: Kuesioner Penelitian, Data diolah Pada

Tahun 2020

Selanjutnya pada tabel 3 yaitu membahas besar peluang peralah seperti yang terlihat dibawah ini

Tabel 3. Peluang Peralihan Empiris $\left(P_{\mathrm{ij}}\right)$

\begin{tabular}{lll}
\hline Merek & AQUA & Le Minerale \\
\hline AQUA & 0,66 & 0,34
\end{tabular}

\begin{tabular}{lll}
\hline Le Minerale & 0,58 & 0,42
\end{tabular}

Sumber: Kuesioner Penelitian, Data diolah Pada Tahun 2020
Kemudian menghitung besar peluang peralihan dari penelitian sebelumnya untuk mendapatkan besar peluang masa mendatang berikut ini:

Tabel 4. Prediksi Proporsi Merek Air Mineral dalam Kemasan Botol

\begin{tabular}{ccc}
\hline \multirow{2}{*}{ Bulan } & \multicolumn{2}{c}{ Persantase Air } \\
& \multicolumn{2}{c}{ Mineral Dalam } \\
\cline { 2 - 3 } & AQUA & Le Minerale \\
\hline September & 62 & 0,38 \\
\hline Oktober & 62,96 & 37,04 \\
\hline November & 63,03 & 36,97 \\
\hline
\end{tabular}

Sumber: kuesioner penelitian, data diolah pada tahun 2020

Tabel 5. Prediksi Proporsi Merek Air Mineral dalam Kemasan Botol Berdasarkan Alasan

\begin{tabular}{lll}
\hline Alasan & AQUA & Le Minerale \\
\hline Brand Awarance & 63 & 37 \\
\hline Brand & 64 & 36
\end{tabular}

Association

\begin{tabular}{lll}
\hline Perceived Quality & 63 & 37 \\
\hline Brand Loyality & 63 & 37 \\
\hline Total & 253 & 147 \\
\hline
\end{tabular}

Sumber: Kuesioner Penelitian, Data diolah Pada Tahun 2020 
Tabel 6. Total dan Rerata

\begin{tabular}{lll}
\hline Total dan rerata & AQUA & $\begin{array}{l}\text { Le } \\
\text { Minerale }\end{array}$ \\
\hline Total & 2,53 & 1,47 \\
\hline Rerata & 0,6325 & 0,3675 \\
\hline
\end{tabular}

Sumber: Kuesioner Penelitian, Data diolah Pada

Tahun 2020

Tabel 7. $\bar{p}_{i j}$ yang Sudah Diatur

\begin{tabular}{lll}
\hline$-\bar{P}$ & AQUA & Le Minerale \\
\hline AQUA & 0,61 & 0,39 \\
\hline Le Minerale & 0,62 & 0,38
\end{tabular}

Sumber: Kuesioner Penelitian, Data diolah Pada

Tahun 2020

Sehingga didapat hasil akhir yang terlihat seperti yang Tabel 8.

Tabel 8. Persentase Air Mineral dalam Kemasan Botol

\begin{tabular}{ll}
\hline AQUA & Le Minerale \\
\hline 61,37 & 38,63
\end{tabular}

Sumber: Kuesioner Penelitian, Data diolah Pada

Tahun 2020

Berdasarkan limiting probability dapat ditentukan dengan menggunakan matriks Peluang transisi $\mathrm{P}$ dan menentukan distribusi stasioner sebagai berikut

$\operatorname{AQUA}(a)=0,6137$

Le Minerale $(b)=0,3863$

$$
\begin{aligned}
p & =\left(\begin{array}{cc}
1-a & a \\
b & 1-b
\end{array}\right) \\
\frac{b}{a+b} & =\frac{0,3863}{0.6137+0,3863}=0,3863
\end{aligned}
$$

$$
\frac{a}{a+b}=\frac{0,6137}{0,6137+0,3863}=0,6137
$$$$
=(0,38630,6137)
$$$$
\pi_{\text {Lemineral }}=38,63
$$$$
\pi_{\text {Aqua }}=61,37
$$

Sehingga didapat besar peluang yang memilih Aqua $61,37 \%$ dan peluang Le-Minerale 38,63\%

\section{Analisis Hasil Rantai Markov Orde dua}

Data penelitian didapat dari hasil penelitian rantai markov orde satu yang dapat dillihat pada tabel 9.

Tabel 9. Data Jumlah Pelanggan Sekarang dan Sebelumnya

\begin{tabular}{lll}
\hline Merek & Sebelumnya & Saat ini \\
\hline AQUA & 62 & 61 \\
\hline Le Minerale & 38 & 39 \\
\hline Total & $\mathbf{1 0 0}$ & $\mathbf{1 0 0}$ \\
\hline $\begin{array}{l}\text { Sumber: Kuesioner Penelitian, Data diolah Pada } \\
\text { tahun 2020 }\end{array}$
\end{tabular}

Selanjutnya pada tabel 10 yaitu membahas besar peluang peralihan pelanggan seperti yang terlihat dibawah ini 
Tabel 10. Kontigensi Pelanggan dari Satu Merek ke Merek Lain

\begin{tabular}{llll}
\hline \multirow{2}{*}{$\begin{array}{l}\text { Mama } \\
\text { Merek }\end{array}$} & \multicolumn{2}{l}{ Ke Merek } & Sebelu \\
\cline { 2 - 3 } & AQUA & Le Minerale & mnya \\
\hline AQUA & 39 & 25 & 62 \\
\hline Le & 23 & 14 & 38 \\
Minerale & & & \\
\hline Saat ini & $\mathbf{6 1}$ & $\mathbf{3 9}$ & $\mathbf{1 0 0}$
\end{tabular}

Sumber: Kuesioner Penelitian, Data diolah Pada

Tahun 2020

Kemudian menghitung besar peluang peralihan dari penelitian sebelumnya untuk mendapatkan besar peluang masa mendatang berikut ini:

Tabel 11. Peluang Peralihan Empiris $\left(P_{i j}\right)$

\begin{tabular}{lcc}
\hline Merek & AQUA & Le Minerale \\
\hline AQUA & 0,61 & 0,39 \\
\hline Le Minerale & 0.62 & 0.38
\end{tabular}

Sumber: Kuesioner Penelitian, Data diolah Pada

Tahun 2020

Kemudian, menghitung besar peluang peralihan air mineral dalam kemasan di masa mendatang

Tabel 12. Prediksi Proporsi merek Air Mineral dalam Kemasan Botol

\begin{tabular}{lll}
\hline Bulan & \multicolumn{2}{c}{ Peralihan } \\
\cline { 2 - 3 } & AQUA & Le Minerale \\
\hline September & 61 & 39 \\
\hline Oktober & 61,39 & 38,61 \\
\hline November & 61,37 & 38,61 \\
\hline
\end{tabular}

Sumber: Kuesioner Penelitian, Data diolah Pada Tahun 2020

Tabel 13. Prediksi Proporsi Merek Air Mineral dalam Kemasan botol Berdasarkan Alasan

\begin{tabular}{lll}
\hline Alasan & AQUA & Le Minerale \\
\hline Brand Awarance & 63 & 37 \\
\hline Brand Association & 64 & 36 \\
\hline Perceived Quality & 63 & 37 \\
\hline Brand Loyality & 63 & 37 \\
\hline Total & 253 & 147 \\
\hline
\end{tabular}

Sumber: Kuesioner Penelitian, Data diolah Pada

Tahun 2020

Tabel 14. Total dan Rerata

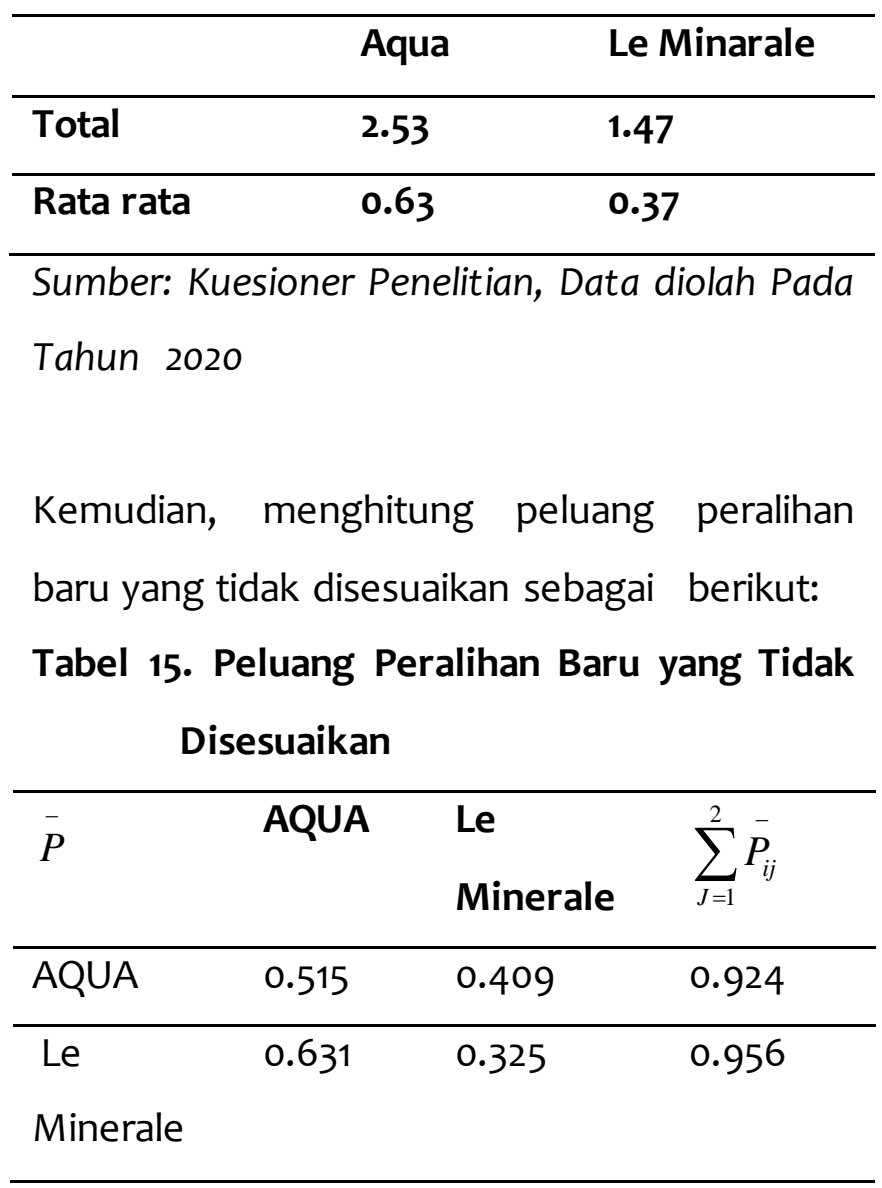


Sumber: Kuesioner Penelitian, Data diolah Pada

Tahun 2020

Tabel 16. $p_{i j}$ yang Sudah Diatur

\begin{tabular}{lll}
\hline $\bar{p}_{i j}$ & AQUA & Le Minerale \\
\hline AQUA & 0.5573 & 0.4426 \\
\hline Le Minerale & 0.66 & 0.3399 \\
\hline
\end{tabular}

Sumber: Kuesioner Penelitian, Data diolah Pada

Tahun 2020

Menghitung peluang peralihan baru untuk mengetahui prediksi pangsa pasar air mineral dalam kemasan botol berdasarkan alasan peralihan pelanggan periode mendatang.

Tabel 17. Prediksi Pangsa Pasar Berdasarkan Alasan Peralihan Periode Mendatang

Persentase Air Mineral dalam Kemasan

AQUA Le Minerale

59,6

40,4

Sumber: Kuesioner Penelitian, Data diolah Pada

Tahun 2020

Berdasarkan limiting probability dapat ditentukan dengan menggunakan matriks Peluang transisi $\mathrm{P}$ dan menentukan distribusi stasioner $\left[\pi_{1} \pi_{2}, \pi_{3}, \ldots, n\right]$ sebagai berikut:

$$
\begin{aligned}
& \text { AQUA }(a)=0,596 \\
& \text { Le Minerale }(\mathrm{b})=0,404 \\
& p=\left(\begin{array}{cc}
1-a & a \\
b & 1-b
\end{array}\right) \\
& \frac{b}{a+b}=\frac{0,404}{0.596+0,404}=0,404
\end{aligned}
$$

$$
\begin{aligned}
& \pi_{\text {Lemineral }}=0,404 \\
& \pi_{\text {Aqua }}=0,596
\end{aligned}
$$$$
\frac{a}{a+b}=\frac{0,596}{0,596+0,404}=0,0596
$$

Sehingga didapat besar peluang yang memilih merek aqua 40,4\% dan peluang merek leminerale $59,6 \%$.

\section{SIMPULAN DAN SARAN}

Kesimpulan yang dirangkum terhadap artikel ini besar peluang peralihan di masa mendatang orde dua yaitu produk AQUA pada September adalah 61\% mengalami kenaikan 0,39\% dari Oktober, pada Oktober adalah 61,39 mengalami penurunan $0,02 \%$ sehingga pada November adalah $61,37 \%$ sedangkan produk Le Mineral pada September adalah 39\% mengalami penurunan 0,39\% dari Oktober, Oktober adalah 38,61\% mengalami penetapan pada November sehingga November 38,61\%. Besar peluang peralihan berdasarkan alasan pelanggan adalah produk AQUA persentasenya lebih besar dari produk Le Minerale yaitu 59,6\% sedangkan produk merek Le Minerale persentasenya sebesar 40,4\%. Pangsa pasar air mineral dalam kemasan botol akan mencapai kondisi stabil pada jangka waktu 3 bulan dimana pangsa pasar pada orde satu AQUA sebesar $61,37 \%$ dan LeMinerale sebesar 38,63\% sedangkan pangsa pasar air mineral dalam kemasan botol orde dua mencapai stabil pada jangka waktu 3 bulan dimana pangsa pasar pada orde kedua adalah 
Produk AQUA adalah 59,6\% sedangkan Le Minerale $40,4 \%$.

\section{Referensi}

Al Bazar, F., \& Aminudin, N. (2018). Program Aplikasi Penjualan Air Mineral Toko Aqua Bill Menggunakan Visual Basic 6.0. Prociding KMSI, 6(1), 119-123.

Deril, M., \& Novirina, H. (2014). Uji Parameter Air Minum Dalam Kemasan (AMDK) di Kota Surabaya. Envirotek: Jurnal Ilmiah Teknik Lingkungan, 6(1), 1-6.

Inayati, S., \& Muhaimi, N. (2019). Penggunaan Rantai Markov Orde Dua untuk Menganalisis Ketersediaan Pemasaran Produk Shampoo Dove di Swalayan Pamella 1 Yogyakarta. Jurnal Matematika Integratif, 15(1), 17-27.

Jain, R. C., \& Ramasubramanian, V. (1998).
Forecasting of crop yields using second order Markov Chains. Journal of the Ind. Soc. of Agril. Stats, 51(1), 61-72.

Purba, J. W. P. (2019). Analisis Strategi Pemasaran Dalam Upaya Peningkatan Pangsa Pasar Perusahaan Studi Kasus: Grand Swiss-Belhotel Medan. JURNAL ILMIAH SIMANTEK, 3(3).

Sandi, F. (2020). Efek Domino Covid-19, Jualan Minuman Amble 40\%. CNBC INDONESIA. Diakses 10 juni 2020 dari https://www.cbnc indonesia.com/efek- domino-covid-19/

Syafina, D. C. (2018). Le-Minerale Versus Aqua Bertarung Di Pasar Berlanjut Di Pengadilan. Diakses 19 September 2020 dari https://tirto.id/le-minerale-verus-aqua bertarung di-pasar-berlanjut-di pengadilan.

Widharta, W. P. (2013). Penyusunan strategi dan sistem penjualan dalam rangka meningkatkan penjualan toko damai. Jurnal Strategi Pemasaran, 1(2), 1-15. 